\title{
EFFECT OF VITAMIN E SUPPLEMENTATION ON MILK YIELD, MILK FATTY ACIDS PROFILE AND ECONOMICAL EFFICIENCY IN BUFFALO COWS
}

\author{
A.M. Kandil, M. A. I. El- Sysy and S. A. Saad \\ Animal Production Department, Faculty of Agriculture, Al-Azhar University, Nasr City, Cairo, Egypt.
}

(Received 6/1/2019, accepted 24/2/2019)

\section{SUMMARY}

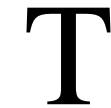

he current study was accomplished to determine the effect of pre-calving administration of vitamin $\mathrm{E}$ on post-partum performance of buffalo cows. Fifteen pregnant buffalo cows of three years age were divided in to 3 groups: Control, treatment $\left(T_{1}\right)$ and treatment $\left(T_{2}\right)$. Control group were given no treatment, $T_{1}$ group was given vitamin $\mathrm{E}(3000 \mathrm{IU} / \mathrm{h} / \mathrm{d})$ whereas; $\mathrm{T}_{2}$ group was given vitamin $\mathrm{E}(6000 \mathrm{IU} / \mathrm{h} / \mathrm{d})$ before 8 week of expected calving even after calving 4 months. Milk yield were different significantly $(\mathrm{P} \leq$ $0.05)$ among treatment groups. $T_{1}$ and $T_{2}$ showed $(P \leq 0.05)$ daily milk yield, being 6.97 and $8.13 \mathrm{~kg}$, respectively. The milk composition was not different $(\mathrm{P} \geq 0.05)$ in all groups. The vaccenic acid and romanic acid was higher in treated groups in comparison with control group. The feed and economic efficiency were higher in treated groups than those of control group. Animal group $\left(\mathrm{T}_{2}\right)$ showed the best both feed efficiency and economic efficiency, being $1.618 \mathrm{~kg} \mathrm{DM}$ per $7 \% \mathrm{~kg} \mathrm{FCM}$ and 1.7 (price of milk yield /feed cost), respectively. Generally, vitamin E supplementation to lactating buffalo cows rations especially higher level (6000 IU) improved actual milk yield and increased feed and economic efficiency.

Keywords: Vitamin E, milk yield, fatty acids profile, economic efficiency and Buffalo.

\section{INTRODUCTION}

Vitamin E is a fat-soluble vitamin and is not synthesized in the rumen. The vitamin E requirement must therefore be provided in the feed. However, the vitamin E content of the basal diet is highly variable and is not known in most situations. Although vitamin E content is high in fresh grass, it markedly reduces during storage and conservation (Persson Waller et al., 2007). Most diseases in dairy cows occur at or just after calving, which is a period associated with immune suppression, resulting in an increased susceptibility to infections, as reported by Mallard, B. A. et al., (1998) and Persson Waller (2000). The vitamin E $(\alpha-$ tocopherol) status of dairy cows is one important component of a well-functioning immune system because of its antioxidant effects on cows (Hogan, et al., 1993; Weiss and Spears, 2006) and young dairy calves (Cipriano, et al., 1982). At parturition, plasma concentrations of vitamin $\mathrm{E}$ were found to decrease by $47 \%$ because of secretion of the vitamin into the udder during colostrogenesis, decreased dry matter intake (DMI) at calving, and an increased need for antioxidants during this time (Goff and Stabel, 1990; Meglia, et al., 2006).

Consumers are increasingly aware of the link between diet and health, and recently fatty acids have gained special attention for their potential health benefits. Conjugated linoleic acid (CLA) is one such bioactive FA that may function to improve health maintenance and prevent chronic diseases. When consumed as a natural component of the diet, cis-9, trans-11 18:2 CLA rumenic acid (RA) has been consistently shown to offer anticarcinogenic and antiatherogenic effects in biomedical studies using animal models of human disease (Parodi, 2004; Bauman et al., 2006). The presence of RA in human diets originates almost exclusively from ruminant-derived milk and meat products (Ritzenthaler et al., 2001). Rumen microbial biohydrogenation of PUFA produces RA and trans-11 18:1 vaccenic acid (VA) as intermediates (Palmquist et al., 2005). Although some RA escapes from the rumen before complete saturation, the major source of RA in milk fat is endogenous synthesis from vaccenic acid (VA) via the mammary enzyme $\Delta 9$ desaturase (Bauman and Lock, 2006). Environmental and physiological factors that affect the milk fat 


\section{Kandil et al.}

content of RA have been identified, with diet having the greatest effect (Chilliard et al., 2000); Palmquist et al., 2005). The ability to minimize risk of diet-induced milk fat depression (MFD) would have potential application and interest in many situations, including the use of diets designed to achieve a sustained increase in milk fat content of CLA. Diet induced MFD results in a characteristic pattern of reduced percentage and yield of milk fat, and a shift in the FA composition of milk fat (Bauman and Griinari, 2003; Harvatine et al., 2009). Results from several recent investigations have suggested a possible role for vitamin $\mathrm{E}$ in preventing the shift in rumen biohydrogenation pathways and subsequent MFD (Charmley and Nicholson, 1994; Focant et al., 1998; Kay et al., 2005; Bell et al., 2006; Pottier et al., 2006).

The aim of the present study was to investigate the effect of vitamin E supplementation in ration on milk yield, composition and in turn its effect on performance of buffalo cows.

\section{MATERIALS AND METHODS}

The present work aimed to study the effect of vitamin E supplement to buffalo cows rations during late pregnancy (60 days pre-partum) and/or lactation (120 days post-partum), and its influences on buffalo cows daily milk yield and its composition (protein, fat, lactose, total solid and solids not-fat \% (SNF) and fatty acid composition). The study was accomplished at throughout the period from October 2016 to March 2017 farm animal production in Mostorod district belonging to Animal Production Department, Faculty of Agriculture, Al-Azhar University, Cairo, Egypt.

\section{Feeding and management of buffaloes:}

Fifteen pregnant Egyptian buffalo cows with an average live body weight $500 \mathrm{~kg}$ and 5 years old age were randomly (according preceding milk yield) assigned into three nutritional groups during late gestation (8 weeks pre-partum).

During the experimental period, routine health management of the farm was followed and animals were having any health disorder were excluded from the study. They were shifted from dry pregnant cow paddocks to the calving pen just one week before the expected calving date and retained till $4-5$ days after calving.

The first group was used as a control $(\mathrm{C})$, nil Vitamin $\mathrm{E}$ supplement. The $2^{\text {nd }}\left(\mathrm{T}_{2}\right)$ and $3^{\text {rd }}$ groups $\left(\mathrm{T}_{3}\right)$ were individually received only 3000 and $6000 \mathrm{IU}$ of $\alpha$-tocopherol acetate/h/d, respectively. during late gestation 60 days pre-partum before the expected calving date and/or lactation 120 days post-partum.

In this respect, the United States Pharmacopeia (USP) defines one International unit (IU) of vitamin E as equal to $1 \mathrm{mg}$ of $\alpha$-tocopheryl acetate (NRC 2001) thus, to supplement $6000 \mathrm{IU}$ of vitamin $\mathrm{E}, 6000 \mathrm{mg}$ (equivalent to $6 \mathrm{~g}$ ) and to supplement $3000 \mathrm{IU}$ of vitamin $\mathrm{E}, 3000 \mathrm{mg}$ (equivalent to $3 \mathrm{~g}$ ) of $\alpha$-tocopheryl acetate was offered.

Experimental animals were housed in semi-opened pens, offered their daily requirements during pregnancy and lactation. Concentrate feed mixture (14\% CP and $60 \% \mathrm{TDN})+$ green berseem (Trifolium alexandrinum), + rice straw were offered to pregnant and lactating buffalo cows in two equal meals at 9.00 am and $6.00 \mathrm{pm}$ (Table 1), with the ratio of $4: 2: 2$ for concentrate feed mixture : green berseem : rice straw, as dry matter basis, respectively. Fresh drinking water was freely available all over the day time.

Table (1): Chemical composition of feedstuffs (DM basis \%).

\begin{tabular}{lccccccccc}
\hline Item & \multirow{2}{*}{ DM } & \multicolumn{9}{c}{ Composition as DM basis } & NDF & ADF \\
\cline { 3 - 8 } & & OM & CP & CF & EE & NFE & Ash & & \\
\hline Pelleted CFM & 91.80 & 89.66 & 15.46 & 18.51 & 4.93 & 50.76 & 10.34 & 39.00 & 28.20 \\
Rice Straw & 91.20 & 87.61 & 5.13 & 36.89 & 2.30 & 43.29 & 12.39 & 70.10 & 61.00 \\
Berseem & 14.85 & 84.65 & 15.51 & 26.13 & 1.21 & 41.80 & 15.35 & 41.00 & 33.00 \\
\hline
\end{tabular}

$\mathrm{CFM}=$ Concentrate feed mixture. 


\section{Milk samples:}

Lactating buffalo cows of different experimental groups were daily hand milked two times after calving (colostrum period) until 4 months of calving. Representative biweekly composite milk from morning and evening samples were collected to study buffalo cows quality of milk (protein, fat, lactose, ash, total solid and solids not-fat \% (SNF)) and fatty acid composition during 4 month collection period. Also, actual milk yield was estimated as $7 \%$ milk yield by using the method of Raafat and Saleh (1962) as follow:

$$
7 \% \mathrm{FCM} \text { yield }=0.265 \times \mathrm{MY}(\mathrm{kg})+10.5 \times \mathrm{FY}(\mathrm{kg})
$$

Where: FCM = Fat corrected milk, MY = Milk yield, and FY = Fat yield.

Fat percentage was determined by Gerber method according to British Standard Institution (1951). Solids not fat content was calculated by the difference between total solids and fat content. Lactose content was determined calorimetrically according to Barrnett and Abd El-Tawab (1957). Total nitrogen was determined by the semi-micro Kjeldahl distillation method according to Ling (1963).

\section{Fatty acid analysis:}

Milk samples from each biweekly were combined for FA analysis per buffalo cow. The extraction of milk fat was based on the method of Hara and Radin (1978) and the transmethylation of the esterified FA were acheived according to the method of Christie (1982) as modified by Chouinard et al., (1999).

Chemical composition of concentrates, green fodder and rice straw were analysed according to A.O.A.C. (1990). The methods of Van Soest et al., (1991) were used for NDF and ADF determination.

\section{Statistical analysis:}

Data were subjected to statistical analysis using two-way classification (for milk yield and milk composition) and one-way analysis of variance (for fatty acids), using the general linear Models procedure adopted by statistical package software SAS version 9.1 SAS (2002), Cary, NC., USA. Differences between means were tested for significances using the L.S.D test, according to Duncan (1955). Analysis of variance and least square means was carried out using the following equations:

$$
\mathrm{Y}_{\mathrm{ij}}=\mu+\mathrm{T}_{\mathrm{i}}+\mathrm{M}_{\mathrm{j}}+\mathrm{E}_{\mathrm{ij}} \text { and } \mathrm{Y}_{\mathrm{ij}}=\mu+\mathrm{T}_{\mathrm{i}}+\mathrm{E}_{\mathrm{ij}}
$$

Where: $\mathrm{Y}_{\mathrm{ij}}=$ the observation of the measured parameter, $\mu=$ overall mean, $T_{i}=$ the effect of dietary treatment, $\mathrm{M}_{\mathrm{j}}=$ the effect of sampling time and $\mathrm{E}_{\mathrm{ij}}=$ the random error term.

\section{RESULTS AND DISCUSSION}

\section{Effect of vitamin E supplementation on milk yield:}

Data presented in Table (2) showed the effect of vitamin E supplementation to buffalo cows rations on daily milk yield. It could be noticed that the overall mean of monthly milk yield recorded 174, 209 and 244 $\mathrm{kg}$ for animal fed control, $\mathrm{T}_{1}$ and $\mathrm{T}_{2}$ treatments, respectively. Corresponding values of average daily milk yield were $5.80,6.97$ and $8.13 \mathrm{~kg}$, showing the highest significant $(\mathrm{P}<0.05)$ values with $\mathrm{T}_{2}$ treatment. At the same time, vitamin E supplementation did not have any significant effect among treated groups on buffalo cows concerning milk yield when it added during the pre-partum.

Generally, the $\mathrm{T}_{2}$ containing $6000 \mathrm{IU}$ of vitamin $\mathrm{E}$ appeared to the highest milk yield. Also, overall mean monthly as daily $7 \%$ FCM yield look like the same trend of actual $7 \%$ FCM yeild, showing height milk yield with $\mathrm{T}_{2}$ recording 263 and $8.77 \mathrm{~kg}$ with monthly and daily milk yield, respectively. On the other hand, differences in actual as 7\% FCM yield among succeed periods were not significant, as shown in Table (2).

The eminent protective role of GSH-PX and vitamin E on membrane integrity might epitomize however one of the mechanisms over which selenium and vitamin E boosted milk production (Lacetera et al., 1996).

Sinek et al. (2000) reported an increase of $13.8 \%$ in milk yield of animals supplemented with vitamin E $\alpha$-tocopheroal $9000 \mathrm{IU} / \mathrm{Kg}$ concentrate mixture. The increase in milk yield was assumed to be due to protection of mammary tissue from free radicals. The present results agreed with the results of Anwar et al., (2014), Kafilzadeh, et al., (2014), Salama et al., (2015) and Maurya et al., (2016), while the opposite trend was observed by Chatterjee (2002). 
Table (2): Average daily and total actual and 7 \% FCM yield for buffalo cows during successive periods.

\begin{tabular}{|c|c|c|c|c|}
\hline \multirow{2}{*}{ Item } & \multicolumn{3}{|c|}{ Experimental ration } & \multirow{2}{*}{ Overall mean } \\
\hline & Control & $\mathrm{T} 1$ & T2 & \\
\hline No. of experimental animal & 5 & 5 & 5 & \\
\hline Lactation period (day) & 120 & 120 & 120 & \\
\hline Average Monthly milk yield (kg/head) & & & & \\
\hline $1^{\text {st }}$ month & 161 & 203 & 226 & $197 \pm 27.96$ \\
\hline $2^{\text {nd }}$ month & 175 & 203 & 279 & $219 \pm 29.96$ \\
\hline $3^{\text {rd }}$ month & 190 & 222 & 242 & $218 \pm 28.32$ \\
\hline $4^{\text {th }}$ month & 171 & 209 & 228 & $203 \pm 28.00$ \\
\hline Overall mean & $\begin{array}{l}174^{\mathrm{b}} \pm \\
25.32\end{array}$ & $\begin{array}{l}209^{\mathrm{ab}} \pm \\
17.25\end{array}$ & $\begin{array}{c}244^{\mathrm{a}} \pm \\
19.91\end{array}$ & \\
\hline $\begin{array}{l}\text { Average daily actual milk yield }(\mathrm{kg} / \mathrm{head}) \\
\text { Average Monthly } 7 \% \text { FCM yield }(\mathrm{kg} / \mathrm{head})\end{array}$ & $5.80^{\mathrm{b}}$ & $6.97^{\mathrm{ab}}$ & $8.13^{\mathrm{a}}$ & \\
\hline $1^{\text {st }}$ month & 156 & 225 & 253 & $211 \pm 18.22$ \\
\hline $2^{\text {nd }}$ month & 209 & 202 & 294 & $235 \pm 16.24$ \\
\hline $3^{\text {rd }}$ month & 163 & 235 & 245 & $214 \pm 19.23$ \\
\hline $4^{\text {th }}$ month & 204 & 238 & 261 & $234 \pm 13.54$ \\
\hline Overall mean & $\begin{array}{r}183^{b} \pm \\
16.36\end{array}$ & $\begin{array}{c}225^{\mathrm{ab}} \pm \\
10.18\end{array}$ & $\begin{array}{c}263^{\mathrm{a}} \pm \\
15.74\end{array}$ & \\
\hline Average daily $7 \%$ FCM yield (kg/head) & $6.10^{\mathrm{b}}$ & $7.50^{\mathrm{ab}}$ & $8.77^{\mathrm{a}}$ & \\
\hline
\end{tabular}

\section{Effect of vitamin E supplementation on milk chemical composition:}

Results in Table (3) indicated insignificant differences among groups in buffalo cows milk chemical composition percentages. $T_{1}$ and $T_{2}$ appeared to have lower $(\mathrm{P}<0.05)$ fat and SNF percentages without significant difference between both the two supplemented groups 7.73 and $7.80 \%$ fat versus 8.28 and 8.65 $\%$ SNF, respectively. It was, also, detected that, both of the control buffalo cows and $\mathrm{T}_{2}$ (those having higher milk yield) i.e. 174 and $244 \mathrm{~kg} /$ month, respectively, tended to have almost similar insignificant fat percentages i.e. 8.05 and $7.80 \%$, respectively.

On the other hand, both of $\mathrm{T}_{1}$ and $\mathrm{T}_{2}$ indicated lower SNF i.e. 8.28 and $8.65 \%$, respectively, in compare with the control group. This result might be related to the insignificant differences detected in fat percentages for both the two supplemented groups.

It could be noticed that the overall mean of protein, lactose, SNF, TS and ash contents ranged 3.15 to $3.40 ; 4.74$ to $5.00 ; 8.65$ to $9.18,16.01$ to 17.23 and 0.75 to $0.77 \%$, respectively. However, the significant differences among experimental treatment in all previous characters were not sigificant.

It could be concluded that, dietary vitamin E supplementation of pregnant and lactating buffalo cows did not have any significant impact on milk chemical composition. The results were agreement with those of. Focant et al., (1998); Kay et al., (2005); Awawdeh, (2015) and Kafilzadeh, et al., (2014).

According to Poilitis and Kwai-Hang, (1988) and Pauselli et al., (2004), the only positive effect of dietary vitamin E or/and Se supplementation on all milk chemical characteristics was mainly correlated to mammary glands health. The role of mammary health on milk quality, particularly its effect on somatic cells count, being of great value, since it is mainly interfering with cheese making properties and other better technological characteristics. 
Table (3): Chemical composition of buffalo cows milk as affected by dietary treatments.

\begin{tabular}{|c|c|c|c|c|}
\hline \multirow{2}{*}{ Item } & \multirow{2}{*}{$\begin{array}{c}\text { Time of } \\
\text { measuring }\end{array}$} & \multicolumn{3}{|c|}{ Experimental ration } \\
\hline & & Control & $\mathrm{T}_{1}$ & $\mathrm{~T}_{2}$ \\
\hline \multirow{5}{*}{ Fat $\%(F)$} & $1 \mathrm{~m}$ & 6.76 & 8.06 & 8.16 \\
\hline & $2 \mathrm{~m}$ & 8.90 & 6.96 & 7.53 \\
\hline & $3 m$ & 5.66 & 7.56 & 7.13 \\
\hline & $4 \mathrm{~m}$ & 8.86 & 8.35 & 8.40 \\
\hline & Overall mean & $8.05 \pm 0.30$ & $7.73 \pm 0.19$ & $7.80 \pm 0.26$ \\
\hline \multirow{5}{*}{ Protein $(\mathrm{P})$} & $1 \mathrm{~m}$ & 3.30 & 3.50 & 3.33 \\
\hline & $2 \mathrm{~m}$ & 3.36 & 3.03 & 2.73 \\
\hline & $3 \mathrm{~m}$ & 2.96 & 3.26 & 3.10 \\
\hline & $4 \mathrm{~m}$ & 3.96 & 2.96 & 3.46 \\
\hline & Overall Mean & $3.40 \pm 0.20$ & $3.19 \pm 0.10$ & $3.15 \pm 0.16$ \\
\hline \multirow{5}{*}{ Lactose \% (L) } & $1 \mathrm{~m}$ & 4.86 & 5.23 & 5.06 \\
\hline & $2 \mathrm{~m}$ & 4.93 & 4.50 & 4.06 \\
\hline & $3 \mathrm{~m}$ & 4.36 & 5.00 & 4.73 \\
\hline & $4 \mathrm{~m}$ & 5.86 & 4.33 & 5.10 \\
\hline & Overall Mean & $5.00 \pm 0.32$ & $4.76 \pm 0.17$ & $4.74 \pm 0.25$ \\
\hline \multirow{5}{*}{ Ash \% (A) } & $1 \mathrm{~m}$ & 0.70 & 0.83 & 0.76 \\
\hline & $2 \mathrm{~m}$ & 0.76 & 0.73 & 0.66 \\
\hline & $3 \mathrm{~m}$ & 0.70 & 0.73 & 0.76 \\
\hline & $4 \mathrm{~m}$ & 0.93 & 0.73 & 0.80 \\
\hline & Overall Mean & $0.77 \pm 0.04$ & $0.75 \pm 0.02$ & $0.75 \pm 0.02$ \\
\hline \multirow{5}{*}{ Solids not-fat \% (SNF) } & $1 \mathrm{~m}$ & 8.86 & 8.67 & 9.16 \\
\hline & $2 \mathrm{~m}$ & 9.06 & 8.27 & 7.46 \\
\hline & $3 \mathrm{~m}$ & 8.03 & 9.00 & 8.60 \\
\hline & $4 \mathrm{~m}$ & 10.76 & 7.18 & 9.36 \\
\hline & Overall Mean & $9.18 \pm 0.57$ & $8.28 \pm 0.30$ & $8.65 \pm 0.44$ \\
\hline \multirow{5}{*}{ Total solids \% (TS) } & $1 \mathrm{~m}$ & 15.63 & 16.73 & 17.33 \\
\hline & $2 \mathrm{~m}$ & 17.96 & 15.23 & 15.00 \\
\hline & $3 \mathrm{~m}$ & 15.70 & 16.56 & 15.73 \\
\hline & $4 \mathrm{~m}$ & 19.63 & 15.53 & 17.76 \\
\hline & Overall Mean & $17.23 \pm 0.75$ & $16.01 \pm 0.39$ & $16.45 \pm 0.55$ \\
\hline
\end{tabular}

Control=Concentrate feed mixture : Berseem :Rice straw with ratios of $4: 2: 2(M D$ basis, $T 1=$ Control $+3000 I U$ of $\alpha-$ tocopherol acetate, and $T 2=$ Control +6000 IU of $\alpha$-tocopherol acetate

\section{Effect of vitamin E supplementation on fatty acids profile (\%) in milk fat:}

One focus of the current study was to enhance and sustain Romanic acid RA (C18:2) concentration in milk fat through the dietary addition of vitamin E, and milk FA composition was significantly affected 


\section{Kandil et al.}

(Table 4). Milk fatty acid profiles of cows fed $\mathrm{T}_{1}$ diet (3000 IU) characterized by higher levels of linoleic acid (C18:2) compared with the control group. Pottier et al., (2006) reported that, the addition of vitamin E induced few significant changes in milk fatty acid profile and the high dose of dietary vitamin $\mathrm{E}$ provided significantly increased milk fat content by $17.93 \%$ and yield by $15.56 \%$ and decreased trans-10 C18:1 content by $47.06 \%$. In addition, it managed to significantly increase the daily yields of vaccenic by $102.56 \%$ and rumenic acids by $56.67 \%$.

The supplementation of vitamin E with both two levels (3000 and $6000 \mathrm{IU} /$ day) significantly decreased the level of C15 in milk, whereas it significantly increased the levels of C4 and rumenic acids. However, the graphs showed that, the sequence of administration of vitamin $\mathrm{E}$ had a significantly positive effect on the production of vaccenic acid and rumanic acid. It could be noticed that rumanic acid $(\mathrm{C} 18: 2)$ and vaccenic acid VA (C18:1) were increased in milk fat being doubled in buffalo cows fed vitamin $\mathrm{E}$ treatments $\left(\mathrm{T}_{1}\right.$ and $\mathrm{T}_{2}$ ) compared with non-vitamin E supplemented treatment groups control.

Table (4): Effect of vitamin E supplementation on fatty acids profile (\%).

\begin{tabular}{lcccc}
\hline \multirow{2}{*}{ Item } & & \multicolumn{3}{c}{ Experimental ration } \\
\cline { 3 - 5 } & & $\mathrm{C}$ & $\mathrm{T} 1$ & $\mathrm{~T} 2$ \\
\hline Butyric & $\mathrm{C} 4$ & $0.23^{\mathrm{b}} \pm 0.04$ & $0.48^{\mathrm{ab}} \pm 0.10$ & $0.51^{\mathrm{a}} \pm 0.04$ \\
Caproic & $\mathrm{C} 6$ & $0.25 \pm 0.01$ & $0.33 \pm 0.09$ & $0.28 \pm 0.01$ \\
Caprylic & $\mathrm{C} 8$ & $2.87 \pm 0.97$ & $2.76 \pm 0.76$ & $2.71 \pm 0.72$ \\
Capric & $\mathrm{C} 10$ & $4.53 \pm 1.37$ & $4.52 \pm 1.43$ & $4.20 \pm 1.07$ \\
Lauric & $\mathrm{C} 12$ & $4.90 \pm 0.83$ & $4.23 \pm 0.47$ & $4.95 \pm 0.97$ \\
Myristic & $\mathrm{C} 14$ & $13.31^{\mathrm{ab}} \pm 2.63$ & $9.99^{\mathrm{b}} \pm 1.75$ & $19.38^{\mathrm{a}} \pm 0.73$ \\
Myristoleic & $\mathrm{C} 14: 1$ & $1.63 \pm 0.28$ & $0.71 \pm 0.04$ & $1.00 \pm 0.34$ \\
Palmitic & $\mathrm{C} 16$ & $24.14 \pm 4.56$ & $24.65 \pm 6.95$ & $28.11 \pm 2.50$ \\
Palmitoleic & $\mathrm{C} 16: 1$ & $3.04 \pm 0.86$ & $3.09 \pm 0.46$ & $2.11 \pm 0.41$ \\
Stearic & $\mathrm{C} 18$ & $5.80 \pm 0.94$ & $6.23 \pm 1.09$ & $7.71 \pm 1.67$ \\
Vaccenic acid & $\mathrm{C} 18: 1$ & $8.65 \pm 0.59$ & $13.16 \pm 4.11$ & $17.78 \pm 4.56$ \\
Romanic acid & $\mathrm{C} 18: 2$ & $0.21^{\mathrm{b}} \pm 0.07$ & $0.54^{\mathrm{a}} \pm 0.08$ & $0.46^{\mathrm{ab}} \pm 0.06$
\end{tabular}

$a, b$ and $c$ small letters; means with different superscripts in the same row and column indicated significant differences at $(P<0.05)$.

Control=Concentrate feed mixture $:$ Berseem $:$ Rice straw with ratios of $4: 2: 2(\mathrm{MD}$ basis, $T 1=$ Control $+3000 \mathrm{IU}$ of $\alpha$ tocopherol acetate, and T2 $=$ Control $+6000 I U$ of $\alpha$-tocopherol acetate

Similar patterns for changes in the rumanic and vaccenic content of milk fat were consistent with the fact that $\Delta 9$-desaturase catalyzes the endogenous synthesis of RA from VA (Bauman and Lock, 2006).

\section{Effect of vitamin E supplementation on feed intake and feed utilization efficiency.}

Date presented in Table (5) showed that the averages daily feed unit intake expressed as $\mathrm{kg}$ DM, TDN, and DCP per head were decreased with the experimental groups. The results showed higher DM intake with the $3^{\text {rd }}$ group which fed higher level of vitamin E (6000 IU), recording $14.19 \mathrm{~kg}$ DM versus $13.77 \mathrm{~kg}$ DM with group fed lowest vitamin E (3000 IU), while the control group recorded the height value (14.86) $\mathrm{kg}$ DM.

Generally, increasing vitamin $\mathrm{E}$ level as supplementation treated $\mathrm{T}_{2}$ increased feed unit intake as DM, TDN and DCP. Increasing feed intake with increased vitamin E level showed higher in both actual and 7\% FCM yield, with no significant differences. However, the difference between group feed control ration and those feed $\mathrm{T}_{2}$ ration in milk yield were significant, as shown in Table (2). 
The results show that, the group fed higher level of vitamin E (6000 IU, $\mathrm{T}_{2}$ ) appeared the highest feed efficiency, being $1.745,0.925$ and $0.148 \mathrm{~kg}$ DM, TDN and DCP per kg actual milk, respectively, versus $1.618,0.857$ and $0.138 \mathrm{~kg}$ DM, TDN and DCP kg / $\mathrm{kg} 7$ \% FCM yield.

The results of Table (5) showed that the group fed higher level vitamin $\mathrm{E}\left(\mathrm{T}_{2}\right)$ recorded the highest efficiency followed by those fed lower level of vitamin E $\left(T_{1}\right)$, while the control group was the lowest feed efficiency.

\section{Effect of vitamin E supplementation on feed cost and economic efficiency:}

The results of Table (6) showed that the cost of feed intake were 35.20, 35.50 and 38.34 LE with groups fed intake control, $T_{1}$ and $T_{2}$ rations, respectively, showing the highest feed cost with group fed higher level from vitamin $\mathrm{E}\left(\mathrm{T}_{2}\right)$. However, the opposite trend was shown with daily feed cost $/ \mathrm{kg}$ milk yield recording 6.07, 5.09 and 4.72 LE with control, $\mathrm{T}_{1}$ and $\mathrm{T}_{2}$ rations, respectively. The efficiency expressed as daily feed cost/7\% FCM yield was 5.77, 4.73 and 4.37 LE for groups fed control, $\mathrm{T}_{1}$ and $\mathrm{T}_{2}$ ration, respectively.

From these results, it could be noticed that the feed cost $/ \mathrm{kg}$ actual milk or $7 \%$ FCM yield was decreased with increasing level of vitamin E supplementation. Accordingly, net revenue appeased to increase, recording 11.20, 20.26 and $26.70 \mathrm{LE}$ with control, $\mathrm{T}_{1}$ and $\mathrm{T}_{2}$ ration, respectively. At the same time the net revenue per both actual milk or 7\% FCM yield showed the same previous trend, being 1.93, 2.91 and 3.28 versus 1.84, 2.70 and $3.04 \mathrm{LE}$ with control, $\mathrm{T}_{1}$ and $\mathrm{T}_{2}$ ration, respectively. Also, the economic efficiency showed higher value with heights level of vitamin $\mathrm{E}$, being 1.32, 1.57 and 1.70 with control, $\mathrm{T}_{1}$ and $\mathrm{T}_{2}$ ration, respectively.

Table (5): Average daily feed intake and efficiency of lactating buffalo cows fed different experimental ration.

\begin{tabular}{lccc}
\hline \multirow{2}{*}{ Item } & \multicolumn{3}{c}{ Ration } \\
\cline { 2 - 4 } & Control & $\mathrm{T} 1$ & $\mathrm{~T} 2$ \\
\hline No. of animal & 5 & 5 & 5 \\
Average LBW (kg) & 600 & 580 & 590 \\
Experimental period (day) & 180 & 180 & 180 \\
Av. daily feed unit intake (kg) & & & \\
DM (kg /head) & 14.86 & 13.77 & 14.19 \\
TDN (kg /head) & 7.87 & 7.30 & 7.52 \\
DCP (kg /head) & 1.26 & 1.12 & 1.21 \\
Av. daily actual milk yield (kg) & $5.80^{\mathrm{b}}$ & $6.97^{\mathrm{ab}}$ & $8.13^{\mathrm{a}}$ \\
Av. daily 7\% FCM yield (kg) & $6.10^{\mathrm{b}}$ & $7.50^{\mathrm{ab}}$ & $8.77^{\mathrm{a}}$ \\
Feed efficiency with actual milk: & & & \\
Kg DM/kg milk yield & 2.562 & 1.976 & 1.745 \\
Kg TDN /kg milk yield & 1.357 & 1.047 & 0.925 \\
Kg DCP /kg milk yield & 0.217 & 0.161 & 0.148 \\
Feed efficiency with 7\% FCM: & & & \\
Kg DM/kg 7\% FCM yield & 2.436 & 1.836 & 1.618 \\
Kg TDN/kg 7\% FCM yield & 1.290 & 0.973 & 0.857 \\
Kg DCP/kg 7\% FCM yield & 0.207 & 0.149 & 0.138 \\
\hline$a, b$ a c small & & & \\
\hline
\end{tabular}

$\overline{a, b}$ and $c$ small letters; means with different superscripts in the same row and column indicated significant differences at $(P<0.05)$.

Control=Concentrate feed mixture : Berseem $:$ Rice straw with ratios of $4: 2: 2($ MD basis, T1=Control +3000 IU of $\alpha$ tocopherol acetate, and T2=Control +6000 IU of $\alpha$-tocopherol acetate 
Table (6): Average feed cost and economic efficiency for lactating buffalo cows fed different experimental rations.

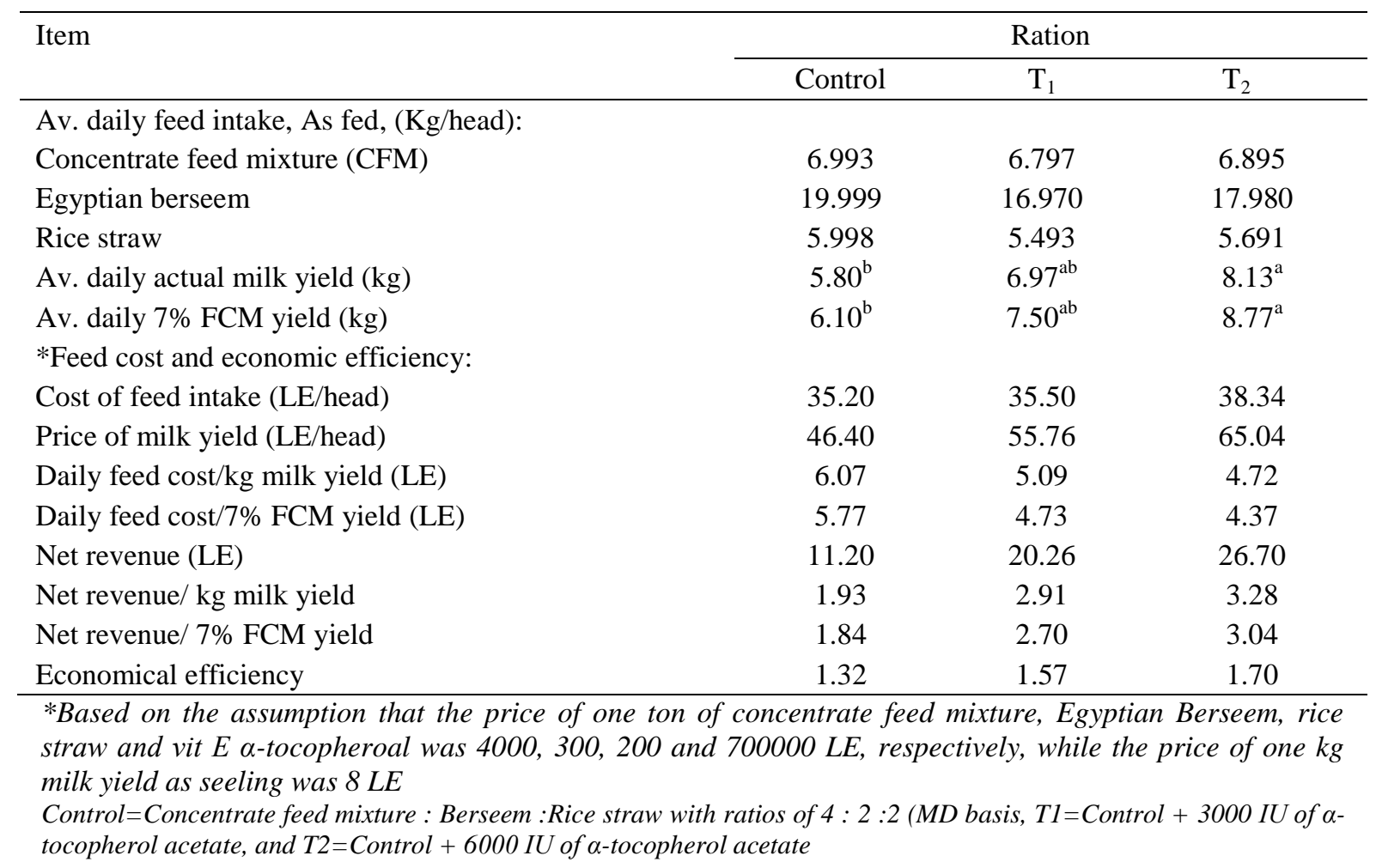

\section{CONCLUSION}

It could be concluded that the higher level of vitamin $\mathrm{E}\left(6000 \mathrm{IU}, \mathrm{T}_{2}\right.$ ) impoved net revenue and economic efficiency comparison with the lower level (3000 TU, T1). Also, groups fed vitamin E supplementation increased milk yield and feed efficiency comparison with the control ration (without supplementation).

\section{REFERENCES}

Anwar, F., M. S. Akhtar, C. Lal, L. A. Lodhi, M. M. Ayaz, I. Ahmad, A. A. Farooq and M. Akhtar (2014). Effect of prepartum administration of selenium and vitamin $\mathrm{E}$ on subsequent postpartum performance in first calf nili-ravi buffalo heifers. The Journal of Animal \& Plant Sciences, 24(Suppl. 1): P: 5-8 : 10187081.

AOAC(1990). Official methods of analysis, $13^{\text {th }}$ Ed. Association of analytical chemists. Washington D.C., USA.

Awawdeh, M. S.; A.Q. Talafha and B.S. Obeidat (2015). Postpartum injection with vitamin E and selenium failed to improve the performance of Awassi ewes and their lambs. Can. J. Anim. Sci. 95: 111-115.

Barrnett, A. J. G. and G. Abd El-Tawab (1957). Determination of lactose in milk and cheese. J. Sci. Food Agric., 8: 437.

Bauman, D. E., and J. M. Griinari (2003). Nutritional regulation of milk fat synthesis. Annu. Rev. Nutr. 23:203-227. 
Bauman, D. E., and A. L. Lock. (2006). Conjugated linoleic acid: Biosynthesis and nutritional significance. Pages 93-136 in Advanced Dairy Chemistry Vol. 2: Lipids.3rd ed. P. F. Fox and P. L. H. McSweeney, ed. Springer, New York, NY.

Bauman, D. E., A. L. Lock, B. A. Corl, C. Ip, A. M. Salter, and P. W. Parodi (2006). Milk fatty acids and human health: Potential role of conjugated linoleic acid and trans fatty acids. Pages 523-555 in Ruminant Physiology: Digestion, Metabolism and Impact of Nutrition on Gene Expression, Immunology and Stress. K. Sejrsen, T. Hvelplund, and M. O. Nielsen, ed. Wageningen Academic Publishers, Wageningen, the Netherlands.

Bell, J. A., J. M. Griinari, and J. J. Kennelly (2006). Effect of safflower oil, flaxseed oil, monensin, and vitamin E on concentration of conjugated linoleic acid in bovine milk fat. J. Dairy Sci. 89:733-748.

British Standard Institution (1951). Gerber method for the determination of fat in milk and milk products.Pub.696.part 2.

Charmley, E., and J. W. G. Nicholson (1994). Influence of dietary fat source on oxidative stability and fatty acid composition of milk from cows receiving a low or high level of dietary vitamin E. Can. J. Anim. Sci. 74:657-664.

Chatterjee, P. N. (2002). Influence of supplementing vitamin E on incidence of mastitis and milk quality of cows. M.Sc. thesis, NDRI (Deemed University), Karnal, India.

Chilliard, Y., A. Ferlay, R. M. Mansbridge, and M. Doreau (2000). Ruminant milk fat plasticity: Nutritional control of saturated, polyunsaturated, trans and conjugated fatty acids. Ann. Zootech. 49:181-205.

Chouinard, P. Y., L. Corneau, D. M. Barbano, L. E. Metzger, and D.E. Bauman (1999). Conjugated linoleic acids alter milk fatty acidcomposition and inhibit milk fat secretion in dairy cows. J. Nutr.129:15791584.

Christie, W. W. (1982). A simple procedure for rapid transmethylation of glycerolipids and cholesteryl esters. J. Lipid Res. 23:1072-1075.

Cipriano, J. E,. J. L. Morrill, and N. V. Anderson (1982). Effect of dietary vitamin E on immune responses of calves. Journal of Dairy Science, 65(12): 2357-2365.

Duncan, D. B. (1955). Multiple range and multiple F-test. Biometrics, 11: 1.

Focant, M., E. Mignolet, M. Marique, F. Clabots, T. Breyne, D. Dalemans, Y. Larondelle, (1998). The effect of vitamin E supplementation of cow diets containing rapeseed and linseed on the prevention of milk fat oxidation. J. Dairy Sci. 81: 1095-1101.

Goff, J. P. and J. R. Stabel (1990). Decreased plasma retinol, $\alpha$ tocopherol and zinc concentration during the periparturientperiod: Effect of milk fever. J. Dairy Sci. 73:3195-3199.

Hara, A., and N. S. Radin (1978). Lipid extraction of tissues with a low-toxicity solvent. Anal. Biochem., 90:420-426.

Harvatine, K. J., Y. R. Boisclair, and D. E. Bauman (2009). Recent advances in the regulation of milk fat synthesis. Animal 3:40-54.

Hogan, J. S., W. P. Weiss, and K. L. Smith (1993). Role of vitamin E and selenium in host defense against mastitis. Journal of Dairy Science, vol. 76, no. 9, pp. 2795-2803.

Kafilzadeh, F., H. Kheirmanesh, H. K. Shabankareh, M. R. Targhibi, E. Maleki, M. Ebrahimi, and G. Y. Meng (2014). Comparing the Effect of Oral Supplementation of Vitamin E, Injective Vitamin E and Selenium or Both during Late Pregnancy on Production and Reproductive Performance and Immune Function of Dairy Cows and Calves. the Scientific World Journal Volume 2014, Article ID 165841, 5 pages.

Kay, J. K., J. R. Roche, E. S. Kolver, N. A. Thomson, and L. H. Baumgard (2005). A comparison between feeding systems (pasture and TMR) and the effect of vitamin E supplementation on plasma and milk fatty acid profiles in dairy cows. J. Dairy Res. 72:322-332. 


\section{Kandil et al.}

Lacetera, N., U. Bernabuci, B. Ronchi and A. Nardone (1996). Effects of selenium and vitamin E administration during a late stage of pregnancy on colostrums and milk production in dairy cows, and on passive immunity and growth of their offspring. American J. Vet. Res., 57: 1776-1780.

Ling, E. R. (1963). Text Book of Dairy Chemistry, L.T.D, London, 559 p.

Mallard, B. A. J. C. Dekkers, M. J. Ireland, K. E. Leslie, S. Sharif, C. L. Vankampen, L. Wagter and B. N. Wilikie (1998). Alteration in immune responsiveness during the peripartum period and its ramification on dairy cows and calf health. Journal of Dairy Science, vol. 81 (2) pp. 589-595.

Maurya, P. K., A. Aggarwal, A. K. Singh and B. K. Chaudhari (2016). Effect of $\alpha$-tocopherol acetate and zinc supplementation on body condition, energy metabolites and milk production in Karan Fries cows. Indian J. Anim. Res., 50 (1): 48-52

Meglia, G. E., S. K. Jensen, C. Lauridsen and K. Persson Waller (2006). $\alpha$-tocopherol concentration and stereoisomer composition in plasma and milk from dairy cows fed natural or synthetic vitamin $\mathrm{E}$ around calving. J. Dairy Res., 73, 227-234.

NRC (2001). Nutrient Requirements of Dairy Cattle. Washington, DC, USA, National Academy Press, 7th revised ed.

Palmquist, D. L., A. L. Lock, K. J. Shingfield, and D. E. Bauman (2005). Biosynthesis of conjugated linoleic acid in ruminants and humans. Adv. Food Nutr., Res., 50:179-217.

Parodi, P. W. (2004). Milk fat in human nutrition. 59:3-59. Aust. J. Dairy. Technol.

Pauselli, M., A. Bolla, C. Casoli and E. Duranti (2004). Effect of vitaminE and selenium administration on sheep milk quality. Atti.14 Congr. Naz. S.I.P.A.O.C. 504-507.

Persson Waller, K. (2000). Mammary gland immunology around parturition. Influence of stress, nutrition and genetics. Advances in Experimental Medicine and Biology, vol. 480, pp. 3488-3497.

Persson Waller, K., C. H. Sandgren, U. Emanuelson, and S. K. Jensen (2007). Supplementation of RRR- $\alpha-$ tocopheryl acetate to periparturient dairy cows in commercial herds with high mastitis incidence. Journal of Dairy Science, vol. 90 (8), 3640. 3646.

Politis, J., and N. G. Kwai-Hang (1988). Effects of somatic cell count and milk composition on cheese composition and cheese making efficiency. J. Dairy Sci.; 71: 1711-1719.

Pottier, J., M. Focant, C. Debier, G. De Buysser, C. Goffe, E. Mignolet, E. Froidmont, and Y. Larondelle (2006). Effect of dietary vitamin $\mathrm{E}$ on rumen biohydrogenation pathways and milk fat depression in dairy cows fed high-fat diets. J. Dairy Sci. 89:685-692.

Raafat, M. A. and M. S. Saleh (1962). Two formula for conversion of cows and buffalos milk of different percentages into milk of standard fat percentage. Proc. The $1^{\text {st }}$ Anim. Prod. Conf. at Minia, P.203.

Ritzenthaler, K. L., M. K. McGuire, R. Falen, T. D. Shultz, N. Dasgupta, and M. A. McGuire (2001). Estimation of conjugated linoleic acid intake by written dietary assessment methodologies underestimates actual intake evaluated by food duplicate methodology. J. Nutr. 131:1548-1554.

Salama, R., M. A. Boraei, M. A. I. El-Sysy and Sh. M. Fouda (2015). Effect of vitamin e supplementation on the productive performance of Rahmani sheep. Egyptian J. Nutrition and Feeds, 18 (2); Special Issue: $65-75$

SAS (2002). Statistical Analysis System. Version 9.1.3. SAS Institute Inc. Cary, NC

Sinek, M., V. Prokop, I. Vrzalova, M. Sustala and D, Zemanova (2000). Trace elements (Cr, Se) and vitamin E in dietary nutrition. Nutr., Abst., Rev., Series. B., 70: 708.

Van Soest P. J., J. B. Robertson and B. A. Lewis (1991). Methods for dietary fiber, neutral detergent fiber, and non-starch polysaccharides in relation to animal nutrition. J. Dairy Sci., 74, 3583-3597.

Weiss, W. P. and J. W. Spears (2006). Vitamin and trace mineral effects on immune function of ruminants. Ruminant Physiology, pp. 473-496 


\title{
تأثير أضافة فيتامين هـ على أنتاج اللبن وتركيب دهن اللبن والكفاءة الاقتصاديه فى الجاموس
}

\author{
أحمد تحمد فهمي قتديل ، محمود عبدالفتاح السيسي و سعد أحمد سعد
}

قسم الانتاج الحبيوانسي - كلية الزراعة - جامعه الأزهر - ملينة نصر - مصر.

أجريت هذه الدر اسة بمحطة أبحاث وتجارب مسطرد التابعه لقسم الانتاج الحيو اني ـ كلية الزر اعة بالقاهرة - جامعة الاز هر خلال الفترة

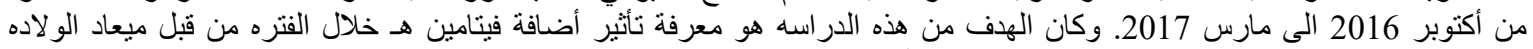

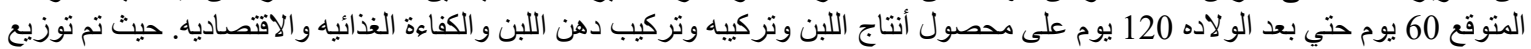

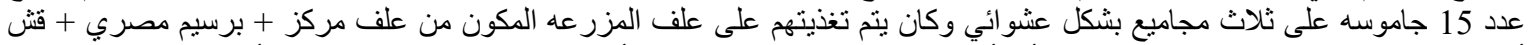

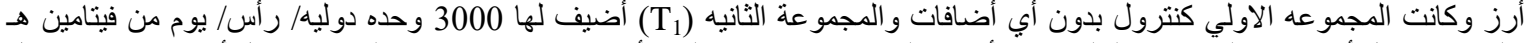

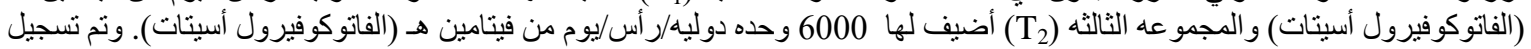

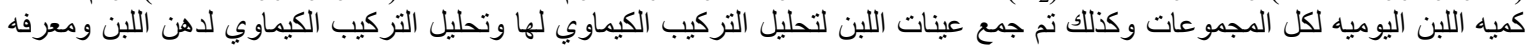

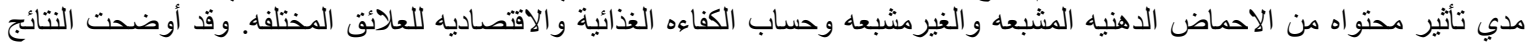

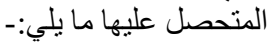

1- زيادة كميه أنتاج اللبن بشكل معنوي فى المجمو عتين المضاف لهما فيتامين هـ مقارنا بالكنترول وكانت المجموعه الثالثه أعلى المجموعات

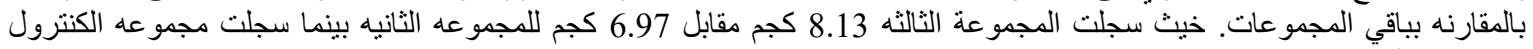



2- لم بلاحظ أي تأثير معنوي على التركيب الكيماوي للبن من حيث كمية الدهن أو البروتين أو اللاكتوز أو الرماد بأضافة الفيتامين من عدمه علي كل المجموعات.

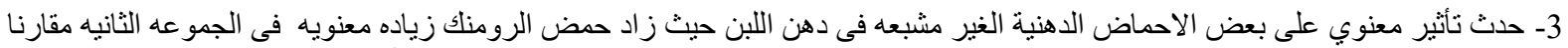

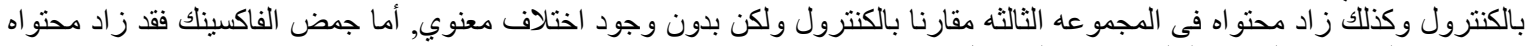

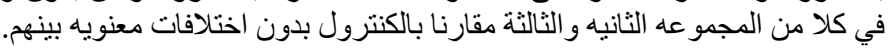

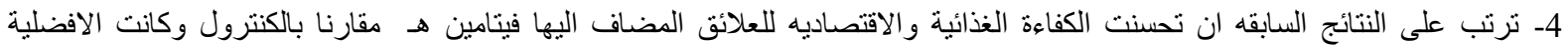



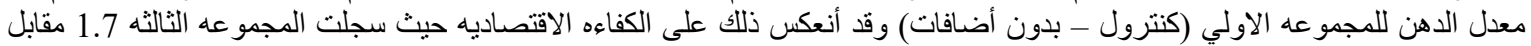
1.32 1.32

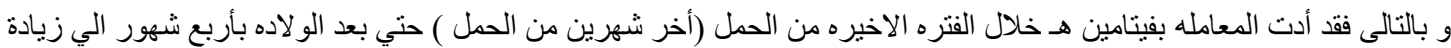

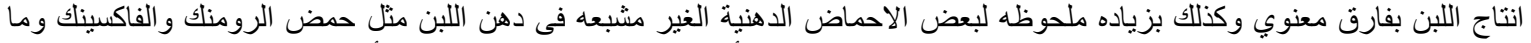

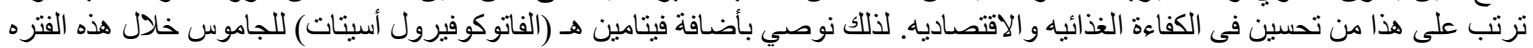

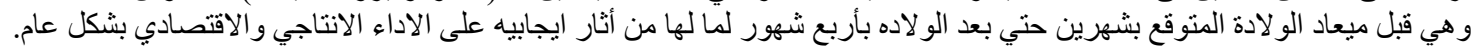

